\title{
SYNTHESIS AND CHARACTERIZATION OF HETEROLEPTIC METAL COMPLEXES OF ISONIAZID AND METFORMIN
}

\author{
Akinyele, O. F. ${ }^{1 *}$, Fakola, E. G ${ }^{1}$, Durosinmi, L. ${ }^{1}{ }^{1}$, Ajayeoba, T. A ${ }^{1}$., Ayeni, A. O \\ Department of Chemistry, Obafemi Awolowo University, Ile-Ife Nigeria \\ *Corresponding Author: Email Address: ofakinyele@oauife.edu.ng/ofakins@yahoo.com Tel: +2348023410301
}

(Received: 28th August, 2019; Accepted: 23rd September, 2019)

\section{ABSTRACT}

Mixed ligand complexes of Metformin and Isoniazid have been synthesized and characterized by solubility studies, percentage metal analysis, UV-Vis spectroscopy, IR spectroscopy, magnetic moments and conductivity measurements. The infrared spectra revealed the coordination of the ligands to the metal ions [manganese(II), cobalt(II), nickel(II), copper(II) and zinc(II)]. Meformin coordinated as a bidentate ligand via the imine nitrogen while isoniazid coordinated through its amino nitrogen $\left(\mathrm{NH}_{2}\right)$ and carbonyl oxygen $(\mathrm{C}=\mathrm{O})$. The electronic spectra and magnetic moments for the complexes strongly suggested a six coordinate octahedral geometry. The molar conductance values of the complexes are within the range $0.45-8.72 \Omega^{-1} \mathrm{~cm}^{2} \mathrm{~mol}^{-1}$, and this confirms the non-electrolytic nature of the complexes.

\section{INTRODUCTION}

1,1-dimethylbiguanide hydrochloride commonly known as metformin hydrochloride is a wellknown anti-diabetics drug, it is primarily used for type 2 diabetes, but is increasingly having a role in treating polycystic ovarian syndrome which can cause obesity and infertility (Aljada and Mousa, 2012). It acts by lowering blood glucose levels primarily by decreasing the amount of glucose produced by the liver. It can also decrease the amount of sugar absorbed into the body (from the diet) and can make insulin receptors in muscle tissue more sensitive, thereby helping the body respond better to its own insulin. A side effect of metformin may be diarrhea, but this is improved when the drug is taken with food, other effects include cramps, nausea, vomiting, and increased flatulence than most other anti-diabetic drugs (Bolen et al, 2007: Khurana and Malik, 2010).

Isonicotinylhydrazide commonly known as isoniazid was introduced into medical practice in 1952 and is used in the treatment of tuberculosis (Donald, 2010). Complexes of isoniazid have been reported to be relatively stable as well as exhibit interesting biological activities (Botarri et al., 2000). This has led to increased studies with respect to the synthesis and structural elucidation of metformin and isoniazid complexes (Al-Abdali et al., 2015; Bamigboye et al., 2012; Sharma et al., 2011)
However studies on the synthesis, and structural elucidation of the mixed ligand complexes of metformin and Isoniazid, has not been reported hence this study. The results of the study are herein reported.

\section{EXPERIMENTAL}

All the chemicals and solvents used in the study were obtained from $\mathrm{BDH}$ and Bond Pharmaceutical, Awe, Oyo State, Nigeria. They were used without further purification. They are Isonicotinylhydrazide (Isoniazid), 1,1dimethylbiguanide hydrochloride (Metfomin), Sodium hydroxide pellets, nitric acid, dimethylsulphoxide (DMSO), dimethyformamide (DMF), hexane, diethylether, acetone, acetonitrile, methanol, ethanol, perchloric acid, hydrochloric acid, copper(II) chloride dihydrate, nickel(II) chloride hexahydrate, zinc(II) chloride, cobalt(II) chloride hexahydrate, manganese(II) chloride tetrahydrate. The percentage metal content was determined using EDTA and atomic absorption spectroscopy (AAS). The infrared spectra were recorded in the $4000-400 \mathrm{~cm}^{-1}$ region with a Shimadzu FT-IR 8000 spectrophotometer using $\mathrm{KBr}$ pellets. UV-Visible spectra of the samples were measured in the range $800-200 \mathrm{~nm}$ using a Shimadzu UV-Vis 1800 spectrophotometer. Magnetic susceptibility measurements were carried out at room temperature using a Sherwood Scientific MXI model Gouy magnetic while the melting points of the compounds were 
determined using a Gallenkamp melting point apparatus.

\section{Synthesis of mixed ligand complexes}

Solution of each of the metal salts $(1.0 \mathrm{mmol}$ of $\mathrm{CoCl}_{2} \cdot 6 \mathrm{H}_{2} \mathrm{O}, \mathrm{CuCl}_{2} \cdot 2 \mathrm{H}_{2} \mathrm{O}, \mathrm{MnCl}_{2} \cdot 4 \mathrm{H}_{2} \mathrm{O}, \mathrm{ZnCl}_{2}$, $\left.\mathrm{NiCl}_{2} \cdot 6 \mathrm{H}_{2} \mathrm{O}\right)$ in $10 \mathrm{ml}$ of methanol was added dropwise into stirring methanolic $\mathrm{NaOH}$ solution of metformin hydrochloride $(2.0 \mathrm{mmol})$ and isoniazid $(1.0 \mathrm{mmol})$. The solution was stirred for two hours, during which precipitate was formed. The product was filtered, washed with excess ethanol and dried over anhydrous calcium chloride.

\section{RESULTS AND DISCUSSION}

The mixed ligand complexes showed high melting points and displayed a variety of colours ranging from black to blue. The complexes had high melting points with a range of $280-350^{\circ} \mathrm{C}$. These high melting points when compared to that of metformin and isoniazid, $223-226^{\circ} \mathrm{C}$ and $170-$ $173{ }^{\circ} \mathrm{C}$ respectively suggest high thermal stability of the synthesized complexes. The theoretical \% metal in the mixed ligand complexes of metformin with isoniazid showed a fairly good correlation with the experimental values as shown in Table 1. The complexes were obtained in appreciable yield ranging from $55.71-75.32 \%$. The reaction of isoniazid and metformin hydrochloride with hydrated metal salts in methanolic sodium hydroxide produces the mixed ligand metal complexes displayed in Equation 1. All the complexes synthesized were insoluble in water and other common solvents, except dimethylsufoxide (DMSO).

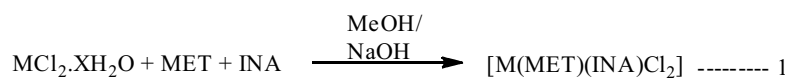

Table1: Physical properties and analytical data for compounds

\begin{tabular}{|c|c|c|c|c|c|}
\hline COMPOUNDS & $\begin{array}{c}\text { Formula/(formula } \\
\text { weight(g) }\end{array}$ & Colour & $\begin{array}{c}\text { Melting point } \\
\left({ }^{\circ} \mathrm{C}\right)\end{array}$ & $\begin{array}{c}\% \text { metal found } \\
\text { (calc) }\end{array}$ & \% yield \\
\hline MET & $\mathrm{C}_{4} \mathrm{~N}_{5} \mathrm{H}_{11}(129.167)$ & White & $223-226$ & - & - \\
\hline INA & $\mathrm{C}_{6} \mathrm{~N}_{3} \mathrm{H}_{7} \mathrm{O}(137.142)$ & White & $170-173$ & - & - \\
\hline $\begin{array}{c}\left.\text { [Mn(MET)(INA) } \mathrm{Cl}_{2}\right] \cdot \\
2 \mathrm{H}_{2} \mathrm{O}\end{array}$ & $\begin{array}{c}\mathrm{C}_{10} \mathrm{~N}_{8} \mathrm{H}_{22} \mathrm{O}_{3} \mathrm{Cl}_{2} \mathrm{Mn} \\
(428.249)\end{array}$ & Black & 292 & $13.10(12.83)$ & 68.13 \\
\hline $\begin{array}{c}{\left[\mathrm{Co}(\mathrm{MET})(\mathrm{INA}) \mathrm{Cl}_{2}\right] \cdot} \\
2 \mathrm{H}_{2} \mathrm{O}\end{array}$ & $\begin{array}{c}\mathrm{C}_{10} \mathrm{~N}_{8} \mathrm{H}_{22} \mathrm{O}_{3} \mathrm{Cl}_{2} \mathrm{Co} \\
(432.239)\end{array}$ & Dark brown & $>300$ & $14.00(13.63)$ & 55.71 \\
\hline$\left[\mathrm{Ni}(\mathrm{MET})(\mathrm{INA}) \mathrm{Cl}_{2}\right]$ & $\begin{array}{c}\mathrm{C}_{10} \mathrm{~N}_{8} \mathrm{H}_{18} \mathrm{OCl} \mathrm{OC}_{2} \mathrm{Ni} \\
(396.002)\end{array}$ & Yellow & $>300$ & $14.03(14.82)$ & 75.32 \\
\hline$\left[\mathrm{Cu}(\mathrm{MET})(\mathrm{INA}) \mathrm{Cl}_{2}\right]$ & $\begin{array}{c}\mathrm{C}_{10} \mathrm{~N}_{8} \mathrm{H}_{18} \mathrm{OCl} \mathrm{OCu}_{2} \mathrm{Cu} \\
(400.859)\end{array}$ & Blue & $>300$ & $15.18(14.54)$ & 54.54 \\
\hline$\left[\mathrm{Zn}(\mathrm{MET})(\mathrm{INA}) \mathrm{Cl}_{2}\right]$ & $\begin{array}{c}\mathrm{C}_{10} \mathrm{~N}_{8} \mathrm{H}_{18} \mathrm{OCl} \mathrm{OCn}_{2} \mathrm{Zn} \\
(402.718)\end{array}$ & White & $>300$ & $15.63(16.23)$ & 59.90 \\
\hline
\end{tabular}

\section{Infrared Spectra}

The infrared spectra data of the metal(II) complexes of Metformin and Isoniazid are shown in Table 2, while the representative infrared spectrum is displayed in Figure 1.

From the infrared interpretation of the ligands, there are various specific bands of importance In the Isoniazid spectrum there are two (Gunasekaran. et al., 2009; Socrates, 2004). These vibrational bands at 3300 and $3209 \mathrm{~cm}^{-1}$ while the bands are due to the amido group $(\mathrm{N}-\mathrm{H})$, carbonyl bands at 3300 and $3176 \mathrm{~cm}^{-1}$ in the metformin group $\mathrm{v}(\mathrm{C}=\mathrm{O})$, and imine group $\mathrm{v}(\mathrm{C}=\mathrm{N})$, found in spectrum correspond to asymmetric and both ligands and $\mathrm{C}-\mathrm{N}$ which occurs in metformin. symmetric stretching of $-\mathrm{NH}_{2}$ group. In all the These bands undergo shifts on complexation which metal(II) complexes, with the exception of $\mathrm{Co}(\mathrm{II})$ provides an evidence of coordination. Additional bands due to metal-oxygen and metal-nitrogen bond which were absent in the spectra of the ligands are usually observed in the spectra of the metal complexes which further provide further evidence for coordination (Neelamma et al., 2010). 
and $\mathrm{Mn}(\mathrm{II})$ complexes which showed broad band of $\mathrm{v}(\mathrm{O}-\mathrm{H})$ at 3425 and $3414 \mathrm{~cm}^{-1}$, the band assigned as $\mathrm{v}(\mathrm{N}-\mathrm{H})$ in the metformin spectrum at $3372 \mathrm{~cm}^{-1}$ showed a shift to lower frequencies in the complexes, strongly suggesting metal ion coordination.

The infrared spectra of the complexes revealed that isoniazid acted as a bidentate ligand coordinating through the amino nitrogen $\left(\mathrm{NH}_{2}\right)$ and carbonyl oxygen $(\mathrm{C}=\mathrm{O})$. The carbonyl $\mathrm{v}(\mathrm{C}=\mathrm{O})$ appeared at band $1667 \mathrm{~cm}^{-1}$. In the metal(II) complexes this band shifted to lower frequencies, with differences of $30-40 \mathrm{~cm}^{-1}$, thus suggesting metal coordination through the carbonyl $(-\mathrm{C}=\mathrm{O})$ group (Gunasekaran. et al.,
2009). On the other hand, the $\mathrm{v}(\mathrm{N}-\mathrm{H})$ in the Isoniazid spectrum at $3114 \mathrm{~cm}^{-1}$ showed shifts to higher frequencies in the complexes, revealing that the amide nitrogen of the isoniazid did not take part in coordination (Gunasekaran. et al., 2009). However in $\mathrm{Co}(\mathrm{II})$ and $\mathrm{Mn}$ (II) complexes, a broad band of $\mathrm{v}(\mathrm{O}-\mathrm{H})$ at 3425 and $3414 \mathrm{~cm}^{-1}$ was observed thus confirming the presence of water molecules in the complexes.

The appearance of new bands at the low frequency region of the infrared spectra gives an evidence of coordination as the bands were assigned to $\mathrm{M}-\mathrm{N}$ and $\mathrm{M}-\mathrm{O}$ stretching vibrations (Kriza et al., 2010).

Table 2: Infrared spectral data of complexes of metformin with isoniazid $\left(\mathrm{cm}^{-1}\right)$

\begin{tabular}{|c|c|c|c|c|c|c|c|c|c|}
\hline Compounds & $\mathrm{V}_{(\mathrm{O}-\mathrm{H})}$ & $V_{(\mathrm{N}-\mathrm{H})}$ & $v_{(\mathrm{N}-\mathrm{H})}$ & $V_{(C=O)}$ & $V_{C=N)}$ & $v_{(C-N)}$ & $V_{(\mathrm{en}) \mathrm{py}}$ & $v_{(M-N)}$ & $\mathrm{V}_{(\mathrm{M}-\mathrm{O})}$ \\
\hline MET & - & $3372 w$ & $\begin{array}{l}3300, \\
3176 \mathrm{~m}\end{array}$ & - & - & $1170 \mathrm{~m}$ & - & - & - \\
\hline INA & - & 3114 & $\begin{array}{l}3300 \\
3204\end{array}$ & 1667 & 1334 & - & $\begin{array}{l}1635 \\
1557\end{array}$ & - & - \\
\hline $\begin{array}{l}\left.\text { [Mn(MET)(INA) } \mathrm{Cl}_{2}\right] . \\
2 \mathrm{H}_{2} \mathrm{O}\end{array}$ & $3414 b$ & - & - & 1645 & 1383 & 1188 & $\begin{array}{l}1681, \\
1546\end{array}$ & $611 w$ & $515 w$ \\
\hline $\begin{array}{l}{\left[\mathrm{Co}(\mathrm{MET})(\mathrm{INA}) \mathrm{Cl}_{2}\right] .} \\
2 \mathrm{H}_{2} \mathrm{O}\end{array}$ & $3425 b$ & - & - & 1645 & 1384 & 1188 & $\begin{array}{l}1681 \\
1548\end{array}$ & $626 \mathrm{w}$ & $561 \mathrm{w}$ \\
\hline$\left[\mathrm{Ni}(\mathrm{MET})(\mathrm{INA}) \mathrm{Cl}_{2}\right]$ & - & 3180 & $\begin{array}{l}3365, \\
3269\end{array}$ & 1643 & 1367 & & $\begin{array}{l}1681, \\
1518\end{array}$ & 646w & $545 w$ \\
\hline$\left[\mathrm{Cu}(\mathrm{MET})(\mathrm{INA}) \mathrm{Cl}_{2}\right]$ & - & 3057 & $\begin{array}{l}3360, \\
3263\end{array}$ & 1633 & 1392 & 1195 & $\begin{array}{l}1672 \\
1566\end{array}$ & $621 \mathrm{w}$ & $530 \mathrm{w}$ \\
\hline$\left[\mathrm{Zn}(\mathrm{MET})(\mathrm{INA}) \mathrm{Cl}_{2}\right]$ & - & 3373 & $\begin{array}{l}3497, \\
3450\end{array}$ & 1633 & 1392 & 1195 & $-\bar{l}-$ & $640 \mathrm{w}$ & $572 \mathrm{w}$ \\
\hline
\end{tabular}

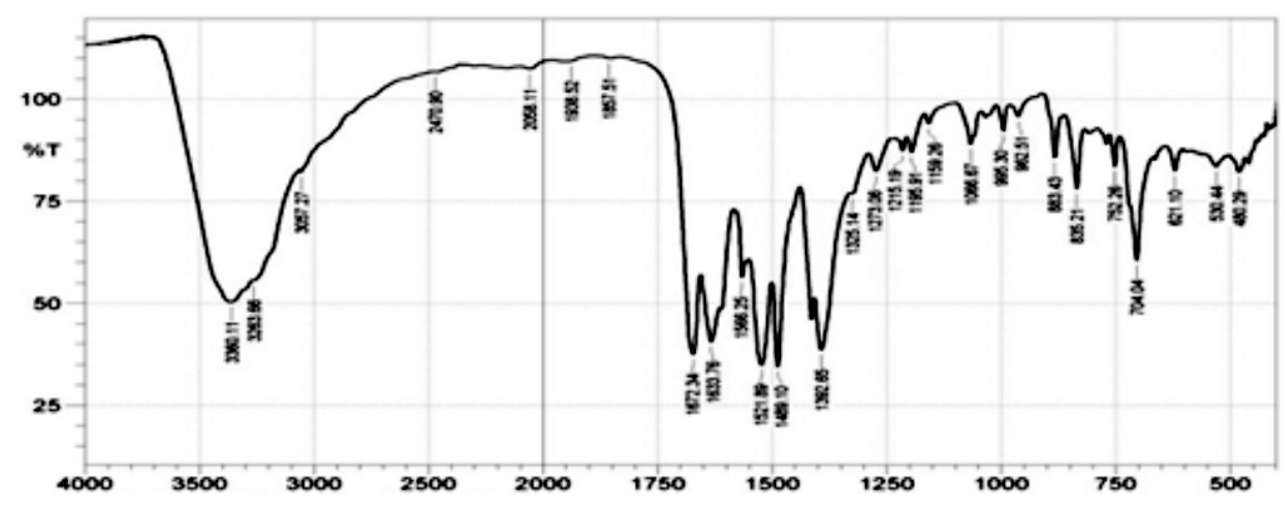

Figure 1: Infra-red spectrum of [Cu(MET)(ISN) $\left.\mathrm{Cl}_{2}\right]$ 


\section{Electronic Spectra}

The electronic spectral data measured in dimethylsulfoxide (DMSO) for the synthesized ${ }^{2}$ mixed ligand complexes is shown in Table 3 , while the electronic spectrum of the copper complex is displayed in Figure 2.

A comparison of the electronic spectra of the free ligands with those of their corresponding metal complexes show some shifts that can be considered as evidence for complex formation (Refat and El-Metwaly, 2012). Upon complexation, the ligand centered bands $\left(n \rightarrow \pi^{*}\right.$, $\pi \rightarrow \pi^{*}$,) undergo an intensity increase with a slight shift relative to the ligand and d-d transitions which are responsible for the characteristic colours of these complexes.

In the UV spectrum of Metformin ligand, a prominent band at $234 \mathrm{~nm}$ is assigned for the intraligand $\mathrm{n} \rightarrow \pi^{*}$ transition in the amide group moiety. The ligand INA showed a sharp band at $263 \mathrm{~nm}$ which is assigned to $\pi \rightarrow \pi^{*}$.

The visible spectrum copper(II) complex of metformin mixed with isoniazid showed a single band at $678 \mathrm{~nm}$ and a shoulder at $528 \mathrm{~nm}$ due to Jahn-Teller distortion. This is consistent with the ${ }^{2} \mathrm{~T}_{2 \mathrm{~g}} \leftarrow{ }^{2} \mathrm{E}_{\mathrm{g}}$ transition in an octahedral environment (Lee, 1996).

In the ligand field spectrum of $\mathrm{Co}(\mathrm{II})$ complex of MET mixed with INA two d-d bands (486, 552 $\mathrm{nm}$ ) are observed. The lowest energy band (high wavelength) at $552 \mathrm{~nm}$ is assigned to the ${ }^{4} \mathrm{~T}_{2} \mathrm{~g} \leftarrow$ ${ }^{4} \mathrm{~T}_{1} \mathrm{~g}$ transition, this assignments supports the proposed octahedral geometry for the complex (Cakir et al., 2001; Lee, 1996).

The visible spectrum of $\mathrm{Ni}(\mathrm{II})$ complex of metformin mixed with isoniazid shows three band at 688,610 , and $418 \mathrm{~nm}$. The bands are due to ${ }^{3} \mathrm{~T}_{1 \mathrm{~g}}$ $\leftarrow{ }^{3} \mathrm{~A}_{2 \mathrm{~g}},{ }^{3} \mathrm{~T}_{1 \mathrm{~g}}(\mathrm{~F}) \leftarrow{ }^{3} \mathrm{~A}_{2 \mathrm{~g}},{ }^{3} \mathrm{~T}_{1 \mathrm{~g}}(\mathrm{P}) \leftarrow{ }^{3} \mathrm{~A}_{2 \mathrm{~g}}$ transitions respectively. The assignments also support octahedral geometry. The Mn(II) complexes of metformin mixed with isoniazid showed weak absorption in the visible region, which is due to spin forbidden transitions (Lee, 1996). There was an absence of bands in the visible region for zinc complexes as they do not undergo d-d transitions (Lee, 1996).

Table 3: The electronic spectral data of complexes of metformin with isoniazid

\begin{tabular}{|c|c|c|c|c|c|}
\hline Compounds & $\begin{array}{l}\text { Intraligand } \\
\text { transition } \\
(\mathrm{nm})\end{array}$ & $\begin{array}{c}\text { Charge } \\
\text { transfer }(\mathrm{nm})\end{array}$ & $\begin{array}{l}\text { Ligand field } \\
\text { d-d transition } \\
(\mathrm{nm})\end{array}$ & Assignment & $\begin{array}{l}\text { Proposed } \\
\text { geometry }\end{array}$ \\
\hline MET & 234 & - & - & - & - \\
\hline INA & 263 & - & - & - & - \\
\hline $\mathrm{C}_{10} \mathrm{~N}_{8} \mathrm{H}_{22} \mathrm{O}_{3} \mathrm{Cl}_{2} \mathrm{Mn}$ & - & 417 & $620,650,671$ & $\begin{array}{l}\text { Low intensity } \\
\text { spin forbidden } \\
\text { transitions }\end{array}$ & Octahedral \\
\hline $\mathrm{C}_{10} \mathrm{~N}_{8} \mathrm{H}_{22} \mathrm{O}_{3} \mathrm{Cl}_{2} \mathrm{Co}$ & 367 & - & $\begin{array}{l}486 \\
552 \\
\end{array}$ & $\begin{array}{l}{ }^{4} \mathrm{~T}_{1} \mathrm{~g} \leftarrow{ }^{4} \mathrm{~A}_{2} \mathrm{~g} \\
{ }^{4} \mathrm{~T}_{1} \mathrm{~g} \leftarrow{ }^{4} \mathrm{~T}_{2} \mathrm{~g}\end{array}$ & Octahedral \\
\hline $\mathrm{C}_{10} \mathrm{~N}_{8} \mathrm{H}_{18} \mathrm{OCl}_{2} \mathrm{Ni}$ & 340 & - & $\begin{array}{l}418 \\
610 \\
688\end{array}$ & $\begin{array}{l}{ }^{3} \mathrm{~T}_{\mathrm{g}}(\mathrm{P}) \leftarrow{ }^{3} \mathrm{~A}_{2 \mathrm{~g}} \\
{ }^{3} \mathrm{~T}_{\mathrm{g}}(\mathrm{F}) \leftarrow{ }^{3} \mathrm{~A}_{2 \mathrm{~g}}, \\
{ }^{3} \mathrm{~T}_{1 \mathrm{~g}} \leftarrow{ }^{3} \mathrm{~A}_{2 \mathrm{~g}},\end{array}$ & Octahedral \\
\hline $\mathrm{C}_{10} \mathrm{~N}_{8} \mathrm{H}_{18} \mathrm{OCl}_{2} \mathrm{Cu}$ & & 358 & 608(sh), 678 & ${ }^{2} \mathrm{~T}_{2 \mathrm{~g}} \leftarrow{ }^{2} \mathrm{E}_{\mathrm{g}}$ & Octahedral \\
\hline $\mathrm{C}_{10} \mathrm{~N}_{8} \mathrm{H}_{18} \mathrm{OCl}_{2} \mathrm{Zn}$ & 298 & - & - & - & Octahedral \\
\hline
\end{tabular}




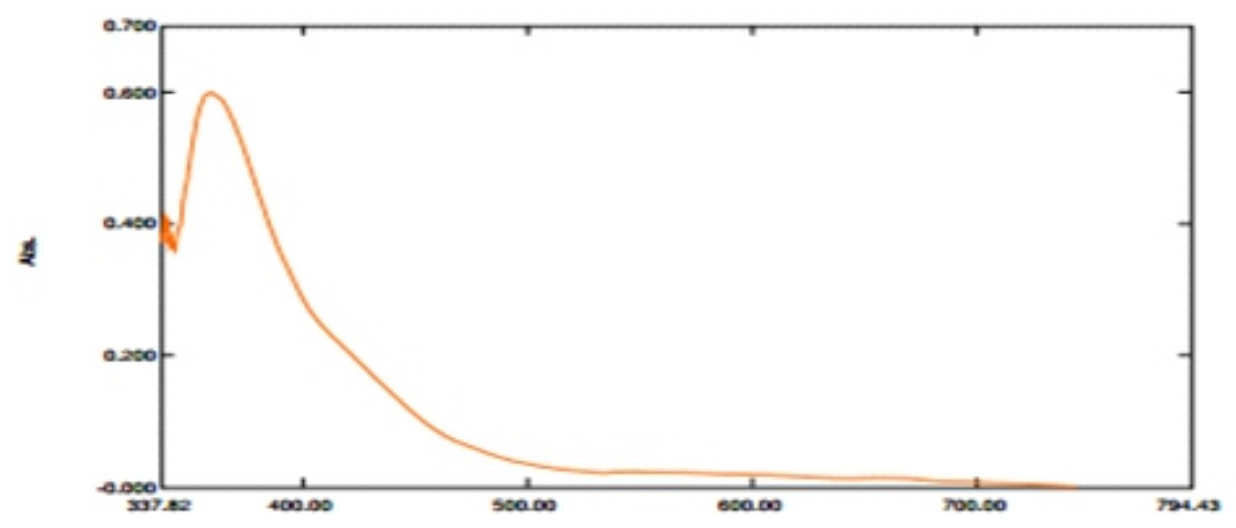

Figure 2: Electronic spectrum of $\left[\mathrm{Cu}(\mathrm{MET})(\mathrm{ISN}) \mathrm{Cl}_{2}\right]$

\section{Magnetic Moment}

All the complexes are paramagnetic while the $\mathrm{Zn}$ (II) complex is diamagnetic. This is shown by the magnetic moment values obtained for the complexes as shown in Table 4. The spin only magnetic moment for copper complex is $1.73 \mathrm{BM}$. The magnetic moment values for copper(II) complex was $1.34 \mathrm{BM}$ which reveals its mononuclear nature and suggests an octahedral geometry. The low value suggests antiferromagnetism (Osowole et al., 2014). The magnetic moment values of $3.18 \mathrm{BM}$ and $2.00 \mathrm{BM}$ for cobalt and nickel complexes respectively supports octahedral geometry, however the values also reveal the likelihood of antiferromagnetism as they are lower than the spin only magnetic moment expected for these complexes (Lee, 1996; Akinyele et al. 2019). The magnetic moment value for manganese complex was $5.95 \mathrm{BM}$ this strongly suggests an octahedral geometry (Lee, 1996). The values derived from the UV-Visible spectroscopic data and magnetic moments suggest an octahedral geometry for the complexes.

Table 4: Magnetic susceptibility data of the complexes of metformin with isoniazid

\begin{tabular}{|c|l|c|c|}
\hline Compounds & Temp. $(\mathrm{K})$ & $\mu_{\text {eff }}(\mathrm{BM})$ & $\mu_{\mathrm{s}}(\mathrm{BM})$ \\
\hline $\mathrm{C}_{10} \mathrm{~N}_{8} \mathrm{H}_{22} \mathrm{O}_{3} \mathrm{Cl}_{2} \mathrm{Mn}$ & 298 & 5.95 & 5.92 \\
\hline $\mathrm{C}_{10} \mathrm{~N}_{8} \mathrm{H}_{22} \mathrm{O}_{3} \mathrm{Cl}_{2} \mathrm{Co}$ & 298 & 3.18 & 3.87 \\
\hline $\mathrm{C}_{10} \mathrm{~N}_{8} \mathrm{H}_{18} \mathrm{OCl}_{2} \mathrm{Ni}$ & 298 & 2.00 & 2.83 \\
\hline $\mathrm{C}_{10} \mathrm{~N}_{8} \mathrm{H}_{18} \mathrm{OCl}_{2} \mathrm{Cu}$ & 298 & 1.34 & 1.73 \\
\hline $\mathrm{C}_{10} \mathrm{~N}_{8} \mathrm{H}_{18} \mathrm{OCl}_{2} \mathrm{Zn}$ & 298 & Diamagnetic & 0.00 \\
\hline
\end{tabular}

\section{Conductivity measurements}

The conductivity measurement of each complex was done using DMSO and the results are presented in Table 5. The molar conductivities in DMSO for all the complexes are in the range $0.45-8.72 \Omega^{-1}$ $\mathrm{cm}^{2} \mathrm{~mol}^{-1}$, indicating their non-electrolytic nature
(Geary, 1971). The low values of molar conductance indicate that the metal complexes did not dissociate in the solvent, while the chloride ion satisfied both the primary and secondary valencies of the metals as shown in Figure 3. 
Table 5: Molar conductance values of complexes of metformin with isoniazid in $\left(\Omega^{-1} \mathrm{~cm}^{2} \mathrm{~mol}^{-1}\right)$

\begin{tabular}{|l|l|l|}
\hline Compounds & $\Lambda \mathrm{m}\left(\Omega^{-1} \mathrm{~cm}^{2} \mathrm{~mol}^{-1}\right)$ & Solvent \\
\hline$\left[\mathrm{Cu}(\mathrm{MET})(\mathrm{ISN}) \mathrm{Cl}_{2}\right]$ & 8.72 & DMSO \\
\hline$\left[\mathrm{Fe}(\mathrm{MET})(\mathrm{ISN}) \mathrm{Cl}_{2}\right]$ & 6.50 & DMSO \\
\hline$\left[\mathrm{Ni}(\mathrm{MET})(\mathrm{ISN}) \mathrm{Cl}_{2}\right]$ & 3.80 & DMSO \\
\hline$\left[\mathrm{Mn}(\mathrm{MET})(\mathrm{ISN}) \mathrm{Cl}_{2}\right] \cdot 2 \mathrm{H}_{2} \mathrm{O}$ & 0.45 & DMSO \\
\hline$\left[\mathrm{Co}(\mathrm{MET})(\mathrm{ISN}) \mathrm{Cl}_{2}\right] \cdot 2 \mathrm{H}_{2} \mathrm{O}$ & 6.30 & DMSO \\
\hline$\left[\mathrm{Zn}(\mathrm{MET})(\mathrm{ISN}) \mathrm{Cl}_{2}\right]$ & 4.94 & DMSO \\
\hline
\end{tabular}

\section{CONCLUSION}

The synthesis and characterization of $\mathrm{Cu}(\mathrm{II})$, $\mathrm{Ni}(\mathrm{II}), \mathrm{Co}(\mathrm{II}), \mathrm{Mn}(\mathrm{II})$ and $\mathrm{Zn}(\mathrm{II})$ complexes of metformin mixed with isoniazid was carried out. The compounds were characterized by UVVisible spectroscopy, infrared spectroscopy, metal analysis, conductivity and magnetic measurements.

The complexes were insoluble in water and display varying degree of solubility in six common solvents including dimethylsulfoxide (DMSO). The infrared spectra revealed coordination of the ligand to the metal ion via the amine nitrogen $\left(\mathrm{NH}_{2}\right)$, carbonyl $(\mathrm{C}=\mathrm{O})$ of Isoniazid, and the imine $(\mathrm{C}=\mathrm{N})$ nitrogen of metformin. The electronic spectra in conjunction with the magnetic moments suggested a six coordinate octahedral geometry. These observations were supported by the molar conductance values which also suggested the non-electrolytic nature of the complexes.

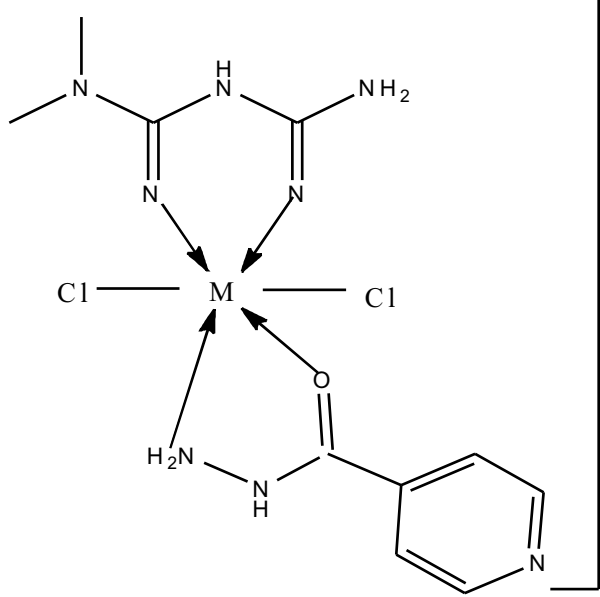

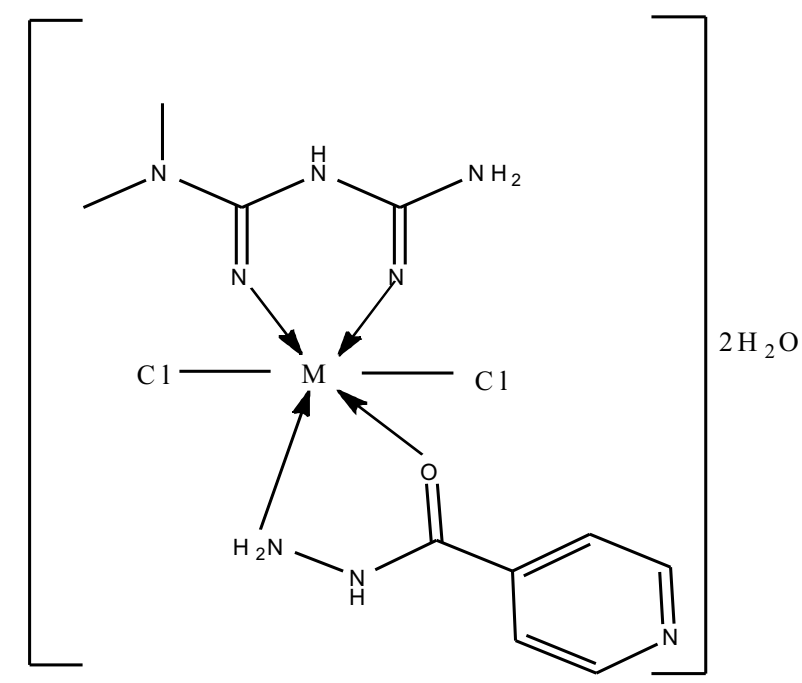
$\mathrm{M}=\mathrm{Ni}^{+2}, \mathrm{Zn}^{+2}, \mathrm{Cu}^{+2}$ $\mathrm{M}=\mathrm{Mn}^{+2}, \mathrm{Co}^{+2}$

Figure 3: Proposed Structure of Mixed Ligand Metal Complexes of Metformin with Isoniazid 


\section{REFERENCES}

Al-Abdali, B. I., Shakir, I. M., and Nafea, H. M. (2015). Synthesis and Spectroscopic Studies of Some Transition Metal Complexes with Mixed ligand of Metformin and Cysteine. IraqiJournal of Science, 56(4B), 3036-3047.

Akinyele, O. F., Akinnusi, T. O., Ajayeoba, T. A., Ayeni, A. O., Durosinmi, L. M. (2019). Synthesis, characterization and antimicrobial activities of Cobalt(II), Nickel(II) and Copper(II) complexes of aroylhydrazone mixed with aspirin. Science Journal of Chemistry, 7(3): 67-71.

Aljada, A., and Mousa, S. A. (2012). Metformin and Neoplasia: Implications and Indications. Pharmacology and Therapeutics, 133(1), 108-115.

Bamigboye, M. O., Obaleye, J. A., Lawal, M., and Aluko, O. M. (2012). Synthesis, Characterization and Antimicrobial Study of Mixed Isoniazid-Trimethoprim Metal Drug Complexes. Chemistry and Materials Research Vol2, No.3, 2012

Bolen, S., Feldman, L., Vassy, J., Wilson, L., Yeh, H. C., Marinopoulos, S., and Brancati, F. L. (2007). Systematic Review: Comparative Effectiveness and Safety of Oral Medications For Type 2 Diabetes Mellitus. Annals of Internal Medicine, 147(6), 386399.

Bottari, B., Maccari, R., Monforte, F., Ottana, R., Rotondo, E., \& Vigorita, M. G. (2000). Isoniazid-related copper (II) and nickel (II) complexes with antimycobacterial in vitro activity. Part 9. Bioorganic and medicinal chemistry letters, 10(7), 657-660.

Cakir, S., Bulut, I., Naumov, P., Bicer, E., and Cakýr, O. (2001). Synthesis and Spectroscopic Studies of Novel $\mathrm{Cu}(\mathrm{II}), \mathrm{Co}(\mathrm{II}), \mathrm{Ni}(\mathrm{II})$ and $\mathrm{Zn}(\mathrm{II})$ mixed ligand complexes with saccharin and nicotinamide. Journal of Molecular Structure, 560(1), 1-7.

Donald, P. R. (2010). The Chemotherapy of Tuberculous Meningitis in Children and Adults. Tuberculosis, 90(6), 375-392.

Geary, W.J (1971). The Use of Conductivity Measurements in Organic Solvents for Characterization of Coordination Compounds. Journal of Coordination Chemistry Revieres.7, 81-83.

Gunasekaran, S., Sailatha, E., Seshadri, S., and
Kumaresan, S. (2009). FTIR, FT Raman Spectra and Molecular Structural Confirmation of Isoniazid.. Indian Journal of Pure and Applied Physics, 47(1), 12-18.

Khurana, R., and Malik, I. S. (2010). Metformin: Safety in Cardiac Patients. Heart, 96(2), 99102.

Kriza, A., Ababei, L. V., Cioatera, N., Rãu, I., \& Stãnicã, N. (2010). Synthesis and structural studies of complexes of $\mathrm{Cu}, \mathrm{Co}$, $\mathrm{Ni}$ and $\mathrm{Zn}$ with isonicotinic acid hydrazide and isonicotinic acid (1naphthylmethylene) hydrazide. Journal of the Serbian Chemical Society, 75(2), 229242.

Lee, J. D. (1996). Concise Inorganic Chemistry, English Language Book Society, London, (32), 954-966.

Neelamma N., Venkateswar R.P., and Anuradha G.H. 2010. Palladium(II) complexes of hydrazones derived from 4dodecyloxybenzoylhydrazine with some aliphatic andaromatic aldehydes and their mesogenic behavior; Indian Journal of Chemistry, 48A; 1078-1084.

Osowole, A. A., Agbaje, O. B., and Ojo, B. O. (2014). Synthesis, Characterization and Antibacterial Properties of Some Heteroleptic Metal(II) Complexes of Paracetamol and Vanillin. Asian Journal of Pharmaceutical and Clinical Research, 7(3), 145-149.

Refat, M. S., and El-Metwaly, N. M. (2012). Spectral, Thermal and Biological Studies of Mn(II) and $\mathrm{Cu}(\mathrm{II})$ Complexes with Two Thiosemicarbazide Derivatives. Spectrochimica Acta Part A: Molecular and Biomolecular Spectroscopy, 92, 336346.

Sharma, S., V Ramani, J., P Dalwadi, D., J Bhalodia, J., K Patel, N., D Patel, D., and K Patel, R. (2011). New Ternary Transition Metal Complexes of 2-\{[(2-aminophenyl)imino] methyl $\}$ Phenol and Metformin: Synthesis, Characterization and Antimicrobial Activity. Journal of Chemistry, 8(1), 361367

Socrates, G. (2004). Infrared and Raman Characteristic Group Frequencies: Tables and Charts. John Wiley E Sons, (22), 292. 